\title{
Purification of wastewater by natural flocculants
}

\author{
Magdalena Czemierska ${ }^{1 *}$, Aleksandra Szczes ${ }^{2}$, ANNA Jarosz-WilkoŁazkA ${ }^{1}$ \\ ${ }^{1}$ Department of Biochemistry, Faculty of Biology and Biotechnology, Maria Curie-Skłodowska University, Lublin, Poland \\ ${ }^{2}$ Department of Interfacial Phenomena, Faculty of Chemistry, Maria Curie-Skłodowska University, Lublin, Poland
}

\begin{abstract}
Bioflocculants are macromolecules produced by microorganisms in response to environmental factors ( $\mathrm{pH}$ value of soil, temperature, presence of metal ions). They are known to possess biosorption abilities and can be applied as wastewater clarifiers. They possess interesting abilities to remove small particles that cannot be removed by any other purification techniques. Bioflocculants may cause aggregation of particles through increasing their molecular weight, which leads to their settlement at the bottom of a water reservoir. Their flocculation abilities can be used for removing metal ions, which are formed in industrial processes (metallurgy, mining, petroleum and chemical industry) as by-products accumulated in aquatic solutions. Biosorption of heavy metals by natural flocculants is possible by neutralization of the surface charge. Flocculants characterized by a negative charge and low zeta potential can aggregate with ions because repulsion forces formed during this process are weaker than van der Waals forces. Further studies on mechanisms of bioflocculation are needed to find a safe and economic way to prevent pollutant accumulation in natural ecosystems.
\end{abstract}

Key words: bioflocculants, aggregation, flocculation, zeta potential

\section{Introduction}

Water is the most important chemical substance found in nature. It covers about $70 \%$ of Earth's surface and is an essential part of all living systems, and therefore it is crucial to protect natural sources of water from contamination. Other factors can also affect the level of water contamination. Chemical substances, such as pigments, heavy metal ions, and other particles, which are produced during industrial processes, can pose serious public health problems ( $\mathrm{Li}$ et al., 2013). Various methods, such as reverse osmosis, electrodialysis, and ion exchange, have been studied to remove pollutants from wastewater. Although there are many different ways to prevent the effects of harmful processes, efforts today must be focused not only on repairing the damage already inflicted, but also on developing efficient methods of water purification that are non-toxic and do not cause secondary pollution (Liu and Cheng, 2010). One of processes that fulfill all these needs is flocculation, a phenomenon observed mostly in solutions.

\section{Natural origin of flocculants}

The mechanism of natural flocculation was first observed in yeast cells by Pasteur (Salehizadeh and Shojaosadati, 2001). Since then, many studies have been conducted to understand this mechanism better; however, there is still a lot to be found about this process and its all potential applications. Therefore, new organisms producing components that are able to carry out flocculation (called flocculants) are being searched. These particular compounds are known as Extracellular Polymeric Substances (EPS) and have been reported in many kinds of organisms such as bacteria, fungi, yeast, and algae (Salehizadeh and Shojaosadati, 2001). Most bioflocculant-producing microorganisms have been isolated from soil and wastewater. The methods of bioflocculant production and purification depend on the type of microorganisms from which the EPS is isolated. Although many microorganisms have been investigated as EPS producers, probably there is still a great number of new organisms with a potential use for flocculant application. 
Table 1. Bioflocculants produced by different kinds of microorganisms

\begin{tabular}{|c|c|c|c|}
\hline Classification & Class of microorganism & Microorganism & References \\
\hline \multirow{23}{*}{ Bacteria } & \multirow{7}{*}{ Actinobacteria } & Arthrobactersp. & Li et al., 2014 \\
\hline & & Brevibacterium insectiphilum & Nakamura et al., 1976 \\
\hline & & Cellulomonas sp. & Nwodo and Okoh, 2012 \\
\hline & & $\begin{array}{l}\text { Corynebacterium brevicale } \\
\text { Corynebacterium glutamicum }\end{array}$ & $\begin{array}{l}\text { Nakamura et al., } 1976 \\
\text { He et al., } 2002\end{array}$ \\
\hline & & Nocardia rhodni & Tong et al., 1999 \\
\hline & & Rhodococcus erythropolis & Kurane et al., 1986 \\
\hline & & Streptomyces vinaceus & Nakamura et al., 1976 \\
\hline & Alphaproteobacteria & Methylobacterium rhodesianum & Tong et al., 1999 \\
\hline & \multirow{6}{*}{ Bacilli } & $\begin{array}{l}\text { Bacillus mucilaginosus } \\
\text { Bacillus sp. } \\
\text { Bacillus subtilis DYU1 }\end{array}$ & $\begin{array}{l}\text { Deng et al., } 2003 \\
\text { Yokoi et al., } 1995 \\
\text { Wu and Ye, } 2007\end{array}$ \\
\hline & & Lactobacillus fermentum & Fumio, 1991 \\
\hline & & Paenibacillus mucilaginosus & Tang et al., 2014 \\
\hline & & Paenibacillus polymyxa SQR-21 & Raza et al., 2011 \\
\hline & & Staphylococcus aureus & Nakamura et al., 1976 \\
\hline & & Solibacillus silvestris & Wan et al., 2013 \\
\hline & Deltaproteobacteria & Nannocystis sp. NU-2 & Zhang et al., 2002 \\
\hline & \multirow{6}{*}{ Gammaproteobacteria } & Azotobacter indicus & Patil et al., 2010 \\
\hline & & Enterobactersp. & Yokoi et al., 1997 \\
\hline & & Proteus mirabilis TJ-1 & Xia et al., 2008 \\
\hline & & Pseudomonas fluorescens & Raza et al., 2012 \\
\hline & & Serratia ficaria & Gong et al., 2008 \\
\hline & & Klebsiella mobilis & Wang et al., 2007 \\
\hline & \multirow{2}{*}{ Proteobacteria } & Agrobacterium sp. & Li et al., 2010 \\
\hline & & Alcaligenes cupidus & Toeda and Kurane, 1991 \\
\hline \multirow{5}{*}{ Algae } & \multirow{2}{*}{ Chlorophyceae } & Chlamydomonas reinhardtii & Bafana, 2013 \\
\hline & & Desmodesmus sp. & Ndikubwimana et al., 2014 \\
\hline & \multirow{2}{*}{ Cyanophyceae } & Calothrix desertica & Bar-Or and Shilo, 1987 \\
\hline & & Oscillatoria sp. & Bender et al., 1994 \\
\hline & Dinophyceae & Gyrodinium impudicum KG03 & Yim et al., 2007 \\
\hline \multirow{7}{*}{ Fungi } & \multirow[t]{2}{*}{ Eurotiomycetes } & $\begin{array}{l}\text { Aspergillus ochraceus } \\
\text { Aspergillus flavus }\end{array}$ & $\begin{array}{l}\text { Nakamura et al., } 1976 \\
\text { Aljuboori et al., } 2013\end{array}$ \\
\hline & & Penicillium sp. & Liu and Cheng, 2010 \\
\hline & Eurotiomycetidae & Monascus anka & Nakamura et al., 1976 \\
\hline & Mucormycotina & Rhizopus sp. & Pu et al., 2014 \\
\hline & \multirow{2}{*}{ Saccharomycetes } & Hansenula anomala & Nam et al., 1996 \\
\hline & & Kluyveromyces marxianus & Sousa et al., 1992 \\
\hline & Sordariomycetes & Pestalotiopsis sp. & Kwon et al., 1996 \\
\hline
\end{tabular}


Table 2. The characteristics of bioflocculants investigated in the last decades

\begin{tabular}{|c|c|c|c|}
\hline Microorganism & Composition of flocculant & Characteristics & References \\
\hline Aspergillus parasiticus & polysaccharide $(76.3 \%)$, protein $(21.6 \%)$ & $\begin{array}{l}\text { the removal of anio- } \\
\text { nic dyes }\end{array}$ & Deng et al., 2005 \\
\hline Bacillus subtilis DYU1 & $\begin{array}{l}\text { polysaccharide }(14.9 \%) \text {, polyami- } \\
\text { des }(48.7 \%) \text {, protein }(4.4 \%)\end{array}$ & $\begin{array}{l}\text { flocculating activity } \\
\text { effective at } \mathrm{pH} \text { 6-7 }\end{array}$ & $\mathrm{Wu}$ and $\mathrm{Ye}, 2007$ \\
\hline Citrobacter sp. BL-4 & $\begin{array}{l}\text { polysaccharide contained glucosa- } \\
\text { mine }(97.3 \%) \text { and rhamnose }(2.7 \%)\end{array}$ & $\begin{array}{l}\text { the structure similar } \\
\text { to chitosan }\end{array}$ & Kim et al., 2006 \\
\hline Corynebacterium glutamicum & polygalacturonic acid & $\begin{array}{l}80 \% \text { flocculating acti- } \\
\text { vity }\end{array}$ & He et al., 2002 \\
\hline Gyrodinium impudicum $\mathrm{KG} 03$ & $\begin{array}{l}\text { polysaccharide contained uronic } \\
\text { acid }(2.9 \%) \text { and sulfate groups }(10.3 \%)\end{array}$ & $\begin{array}{l}\text { effective over a wide } \\
\text { temperature range } \\
\text { and under acidic con- } \\
\text { ditions }\end{array}$ & Yim et al., 2007 \\
\hline Klebsiella pneumoniae MBF-5 & polysaccharide $(96.8 \%)$, protein $(2.1 \%)$ & $\begin{array}{l}\text { the removal of amoe- } \\
\text { bae cysts from water }\end{array}$ & Kobayashi et al., 2002 \\
\hline Nannocystis sp. NU-2 & polysaccharide $(56.5 \%)$, protein $(40.3 \%)$ & $\begin{array}{l}\text { cations }\left(\mathrm{Fe}^{3+} \text { and } \mathrm{Al}^{3+}\right) \\
\text { stimulate flocculating } \\
\text { activity }\end{array}$ & Zhang et al., 2002 \\
\hline Paenibacillus elgii B69 & $\begin{array}{l}\text { polysaccharide (glucose, glucuronic } \\
\text { acid, mannose, xylose) }\end{array}$ & $\begin{array}{l}\text { the application in wa- } \\
\text { stewater treatment }\end{array}$ & Li et al., 2013 \\
\hline Proteus mirabilis TJ-1 & polysaccharide $(63.1 \%)$, protein $(30.9 \%)$ & $\begin{array}{l}\text { the optimal condi- } \\
\text { tions for production: } \\
\mathrm{pH} 7 ; 25^{\circ} \mathrm{C} ; 130 \mathrm{rpm}\end{array}$ & Xia et al., 2008 \\
\hline Solibacillus silvestris W01 & polysaccharide $(75.1 \%)$, protein $(24.9 \%)$ & $\begin{array}{l}\text { the application in har- } \\
\text { vest of Nannochloro- } \\
\text { psis oceanica }\end{array}$ & Wan et al., 2013 \\
\hline
\end{tabular}

Table 1 presents information on the subject of bioflocculants in the context of the past few decades.

The composition and characteristics of a particular bioflocculant depend on the microorganisms producing appropriate polymers. Many factors connected with growth conditions play a crucial role in deriving bioflocculants, and it is very important to optimize the composition of the culture broth and all steps of biopolymer extraction and purification. It has been reported that selection of an appropriate temperature of culture, the $\mathrm{pH}$ value of culture broth, the growth phase of microorganism cultures, carbon and nitrogen sources, and the concentration of inoculum can significantly affect the flocculation activity of the EPSs obtained and the efficiency of their purification. The optimization of the synthesis and the process of purification of natural flocculants from microorganism cultures may encounter two issues limiting applications of these substances in industry. These are the high production cost and the low productivity of particular strains of microorganisms (He et al., 2002). The diversity of natural bioflocculant sources in terms of their composition and properties of analyzed substances can be noticed. Depending on microorganisms, it is possible to obtain products with unique features, characteristic only for a particular type of bacteria, fungi, or algae. Table 2 presents the diversity of the bioflocculants studied and summarizes the basic knowledge about them.

\section{Mechanism of flocculation}

A possible application in industry requires the knowledge of basic mechanisms that can affect properties of products that are pivotal in everyday use. Therefore, it is important to determine the active components of bioflocculants participating in the flocculation process ( $\mathrm{Li}$ et al., 2014). Generally, flocculation is a physicochemical process that occurs between particles suspended in a solution and flocculants-polymeric substances with high floc- 
A
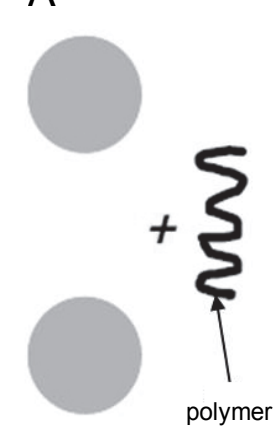

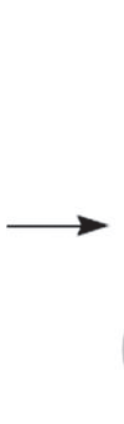

B

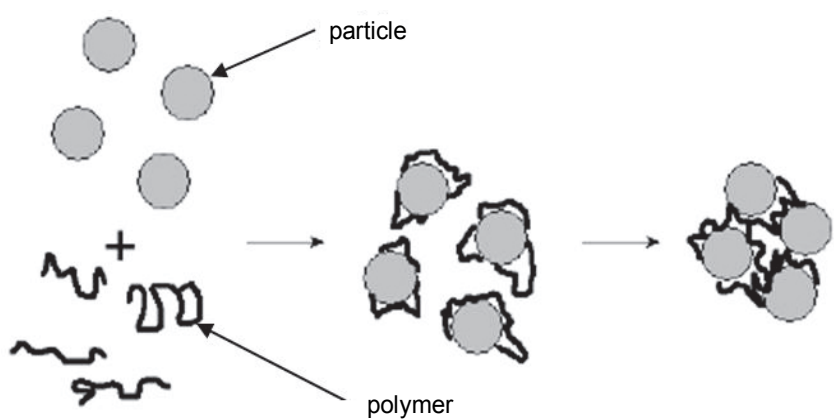

Fig. 1. Bridging mechanism of flocculation process: A) formation of a bridge between particles and the flocculant; B) aggregation of particles bound by a long-chain polymer (http://www.siltstop.com/pdf/flocculation-theory_application.pdf)

culation activities. Bilateral interactions of these two components lead to the formation of bonds that cause agglomeration and, in consequence, sedimentation of the formed molecules. Several explanations for the flocculation mechanism have been offered, for both natural and synthetic flocculants, including a bridging mechanism, an electrostatic patch process, charge neutralization, and displacement as well as depletion of flocculation (Lee et al., 2014). The bridging mechanism describes a majority of the flocculation processes, especially when the function of natural flocculants is investigated (Salehizadeh and Shojaosadati, 2001). The bridging phenomenon occurs in a solution where biopolymers with long chains are present and that these biopolymers can be absorbed concomitantly on more than one particle, binding them together by formation of "bridges" (Fig. 1a). It is required for polymers with long chains to bind to molecules suspended in the solution. The polymer can absorb on colloidal particles during the formation of loops and chains. When another molecule (with free absorption spots) comes across these structures, binding takes place and basic aggregates are formed. This kind of mechanism yields flocs bound more strongly than during other processes and depends on the molecular weight and charge of polymers added to the solution (Tripathy and De, 2006). Another explanation of the flocculation process is based on the natural ability of compounds to possess an electrostatic charge that can be different even between particles present in the same solution. The addition of a biopolymer can reduce the surface charge of individual molecules and can induce reduction of the repulsion force between particles, causing aggregation and formation of flocs (Fig. 1b) (Lee et al., 2014). Therefore, the charge of neutralization depends on van der Waals forces and the zeta potential of the bioflocculant molecule. A higher zeta potential causes the reduction of van der Waals forces, and consequently, no aggregate particles are formed. In contrast, a low zeta potential and strong van der Waals interaction cause aggregation of particles (Lee et al., 2014).

The flocculation process might also be explained by the patch mechanism (Fig. 2), which operates when the polymer added to the solution has a low molecular weight and occurs as a short-chain molecule. In this situation, the polymer is not able to neutralize the electrostatic charges on the whole surface of suspended particles and specific sites (named "islands" or just "patches") are created on the external layer of the particles (Tripathy and De, 2006). This area is a specific space on the surface of the particle where the negative charge is neutralized by positive functional groups of the flocculating polymer. The flocs obtained through this kind of interactions are weaker than those formed during the bridging process, but they are not as loosely bound as those formed during the basic charge neutralization (Lee et al., 2014).

\section{Application of flocculants in wastewater treatment}

Nowadays, the application of flocculants in the water purification process has been thoroughly investigated and verified (Lee et al., 2014). The occurrence of harmful substances from different branches of industry poses a serious problem not only for the environment, but also for human health. It has been reported that the use of synthetic flocculants is efficient but is still not safe for the environment. Therefore, natural flocculants have been intensively studied for the last decades. Despite many advantages like biodegradability, non-toxicity, and 


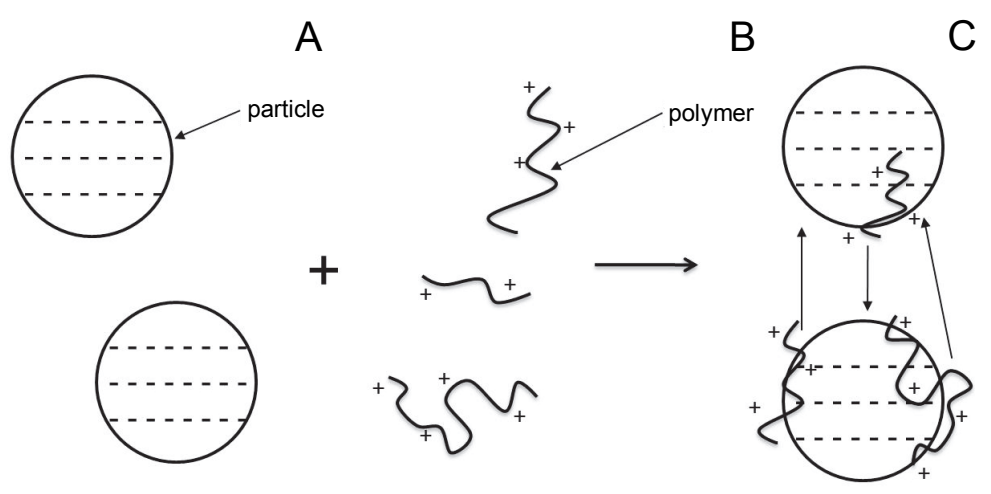

Fig. 2. Electrostatic patch mechanism of flocculation process: negatively charged particles (A); positively charged flocculants (B); interaction between suspended particles (C) (based on Sharma et al., 2006)

diversity of biopolymers with flocculating activity, it is necessary to optimize the whole process of their derivation. Studies on flocculating substances have shown significant productivity in the reduction of specific environmental parameter values, such as total suspended solids (TSS), turbidity, chemical oxygen demand (COD), and the level of decolorization, with $90 \%$ reduction after the application of the polymers studied (Lee et al., 2014). Gong et al. (2008) have reported that an exopolysaccharide from Serratia ficaria can be used in different industrial wastewater treatments, for example, generated during soy sauce brewing and production of pulp and paper. Furthermore, a polysaccharide polymer obtained from Bacillus mucilaginosus is very efficient in the removal of $85 \%$ of suspended solids (SS) from starch wastewater with $68.5 \%$ reduction of COD (Deng et al., 2003). An exopolymer obtained from Paenibacillus elgii strain B69 has been proved to remove COD and turbidity in $68 \%$ and $83 \%$, respectively (Li et al., 2013). In addition, many studies have reported that macromolecules with flocculating activities are able to remove heavy metal ions by biosorption achieved by simple charge neutralization and, in rare cases, by the bridging mechanism and electrostatic patch mechanism (More et al., 2014). Many flocculants can also eliminate dyes from textile industry wastewater. The dye-biosorption ability of EPS is connected with the presence of various functional groups (hydroxyl, amino, phosphate, carboxyl) in the exopolymer molecule, which are responsible for attractive forces between the dye and the biopolymer (More et al., 2014). During this process, most substances present in wastewater are bound and, in consequence, can be removed by filtration or decantation. Further applica- tions of bioflocculants are also interesting and important from the scientific point of view. For example, bioflocculants can separate oil from emulsion, remove cells from culture broths, eliminate toxic organic compounds, and can be useful in wastewater treatment plants (Salehizadeh and Shojaosadati, 2001; More et al., 2014).

\section{Conclusions}

The pollution of environment is an increasing threat to human beings. To protect our environment, we should improve well-known techniques and develop new methods of water purification. The application of natural flocculants is a non-toxic and more eco-friendly solution to purify wastewater from heavy metal ions, dyes, and other suspended particles. Moreover, bioflocculants are biodegradable, which is a desirable feature of this kind of products. The optimization of bioflocculant derivation and purification might be a huge step to an industrial application of these natural substances.

\section{Acknowledgments}

This project was financed by The National Science Center based on decision number DEC-2012/07/B/ST5/01799.

\section{References}

Aljuboori A.H.R., Idris A., Abdullah N., Mohamad R. (2013) Production and characterization of a bioflocculant produced by Aspergillus flavus. Bioresour. Technol. 127: 489493.

Bafana A. (2013) Characterization and optimization of production of exopolysaccharide from Chlamydomonas reinhardtii. Carbohydr. Polym. 95: 746-752.

Bar-Or Y., Shilo M. (1987) Characterization of macromolecular flocculants produced by Phormidium sp. J-1 and by Ana- 
baenopsis circularis PCC 6720. Appl. Environ. Microbiol. 53: 2226-2230.

Bender H., Rodriguez-Eatun S., Ekanemesang U., Phillips P. (1994) Characterization of metal-binding bioflocculants produced by the cyanobacterial component of mixed microbial mats. Appl. Environ. Microbiol. 60: 2311-2315.

Deng S.B., Bai R.B., Hu X.M., Luo Q. (2003) Characteristics of a bioflocculant produced by Bacillus mucilaginosus and its use in starch wastewater treatment. Appl. Microbiol. Biotechnol. 60: 588-593.

Deng S., Yu G., Ting Y.P. (2005) Production of a bioflocculant by Aspergillus parasiticus and its application in dye removal. Colloids Surf. B. 44: 179-186.

Fumio Y. (1991) Flocculation of yeast cells by Lactobacillus fermentum. Res. Microbiol. 22: 12-16.

Gong W.-X., Wang S.-G., Sun X.-F., Liu X.-W., Yue Q.-Y., Gao B.-Y. (2008) Bioflocculant production by culture of Serratia ficaria and its application in wastewater treatment. Bioresour. Technol. 99: 4668-4674.

He N., Li Y., Chen J., Lun S.-Y. (2002) Identification of a novel bioflocculant from a newly isolated Corynebacterium glutamicum. Biochem. Eng. J. 11: 137-148.

Kim L.S., Hong S.J., Son M.K., Lee Y.H. (2006) Polymeric and compositional properties of novel extracellular microbial polyglucosamine biopolymer from new strain of Citrobacter spp. BL-4. Biotechnol. Lett. 28: 241-245.

Kobayashi T., Takiguchi Y., Yazawa Y., Nakata K., Yamaguchi T., Kurane R. (2002) Structural analysis of an extracellular polysaccharide bioflocculant of Klebsiella pneumonia. Biosci. Biotechnol. Biochem. 66: 1524-1530.

Kurane R., Matsuyama H. (1994) Production of a bioflocculant by mixed culture. Biosci. Biotechnol. Biochem. 58: 15891594.

Kwon G.S., Moon S.H., Hong S.D., Lee H.M., Kim H.S., Oh H.M., Yoon B.D. (1996) A novel flocculant biopolymer produced by Pestalotiopsis sp. KCTC-8637. Biotechnol. Lett. 18: 1459-1464.

Lee C.S., Robinson J., Chong M.F. (2014) A review on application of flocculants in wastewater treatment. Process Saf. Environ. Prot. 92: 489-508.

Li Q., Liu H., Qi Q., Wang F., Zhang Y. (2010) Isolation and characterization of temperature and alkaline stable bioflocculant from Agrobacterium sp. M-503. New Biotechnol. 27: 789-794.

Li Q., Lu C., Liu A., Zhu L., Wang P.-M., Qian C.-D., Jiang X.-H., Wu X.-C. (2013) Optimization and characterization of polysaccharide-based bioflocculant produced by Paenibacillus elgii $B 69$ and its application in wastewater treatment. Bioresour. Technol. 134: 87-93.

Li Y., Li Q., Hao D., Hu Z., Song D., Yang M. (2014) Characterization and flocculation mechanism of an alkali-activated polysaccharide flocculant from Arthrobacter sp. B4. Bioresour. Technol. 170: 574-577.

Liu L.-F., Cheng W. (2010) Characteristics and culture conditions of a bioflocculant produced by Penicillium sp. Biomed. Environ. Sci. 23: 213-218.
More T.T., Yadav J.S.S., Yan S., Tyagi R.D., Surampalli R.Y. (2014) Extracellular polymeric substances of bacteria and their potential environmental applications. J. Environ. Manage. 144: 1-25.

Nakamura J., Miyashiro S., Hirose Y. (1976) Screening, isolation and some properties of microbial cell flocculants. Agric. Biol. Chem. 40: 377-383.

Nam J.S., Kwon G.S., Lee S.O., Hwang J.S., Lee J.D., Yoon B.D. (1996) Bioflocculant produced by Aspergillus sp. JS42. Biosci. Biotechnol. Biochem. 60: 325-327.

Ndikubwimana T., Zeng X., Liu Y., Chang J.-S., Lu Y. (2014) Harvesting of microalgae Desmodesmus sp. F51 by bioflocculation with bacterial bioflocculant. Algal Res. 6: 186-193.

Nwodo U.U., Okoh A.I. (2012) Characterization and flocculation properties of biopolymeric flocculant (glycosaminoglycan) produced by Cellulomonas sp. Okoh. J. Appl. Microbiol. 114: 1325-1337.

Patil S.V., Salunkhe R.B., Patil C.D., Patil D.M., Salunke B.K. (2010) Bioflocculant exopolysaccharide production by Azotobacter indicus using flower extract of Madhuca latifolia L. Appl. Biochem. Biotechnol. 162: 1095-1108.

$\mathrm{Pu}$ S., Qin L., Che J., Zhang B., Xua M. (2014) Preparation and application of a novel bioflocculant by two strains of Rhizopus sp. using potato starch wastewater as nutrilite. Bioresour. Technol. 162: 184-191.

Raza W., Makeen K., Wang Y., Xu Y., Qirong S. (2011) Optimization, purification, characterization and antioxidant activity of an extracellular polysaccharide produced by Paenibacillus polymyxa SQR-21. Bioresour. Technol. 102: 6095-6103.

Raza W., Yang W., Jun Y., Shakoor F., Huang Q., Shen Q. (2012) Optimization and characterization of a polysaccharide produced by Pseudomonas fluorescens WR-1 and its antioxidant activity. Carbohydr. Polym. 90: 921-929.

Salehizadeh H., Shojaosadati S.A. (2001) Extracellular biopolymeric flocculants: recent trends and biotechnological importance. Biotechnol. Adv. 19: 371-385.

Shrama B.R., Dhuldhoya N.C., Merchant U.C. (2006) Flocculants - an ecofriendly approach. J. Polym. Environ. 14: 195-202.

Sousa M., Teixeira J., Mota M. (1992) Difference in flocculation mechanism of Kluyveromyces marxianus and Saccharomyces cerevisiae. Biotechnol. Lett. 14: 213-218.

Tang J., Qib S., Lia Z., Ana Q., Xiea M., Yanga B., Wangb Y. (2014) Production, purification and application of polysaccharide-based bioflocculant by Paenibacillus mucilaginosus. Carbohydr. Polym. 113: 463-470.

Toeda K., Kurane R. (1991) Microbial flocculant from Alcaligenes cupidus KT201. Agric. Biol. Chem. 55: 2793-2799.

Tong Z., Zhe L., Huai Z. (1999) Microbial flocculant and its application in environmental protection. J. Environ. Sci. 11: 1-12.

Tripathy T., De B.R. (2006) Flocculation: A new way to treat the waste water. J. Phys. Sci. 10: 93-127.

Wan C., Zhao X.-Q., Guo S.-L., Alam M. A., Bai F.-W. (2013) Bioflocculant production from Solibacillus silvestris W01 
and its application in cost-effective harvest of marine microalga Nannochloropsis oceanica by flocculation. Bioresour. Technol. 135: 207-212.

Wang S.-G., Gonga W.-X., Liu X.-W., Tian L., Yue Q.-Y., Gao B.Y. (2007) Production of a novel bioflocculant by culture of Klebsiella mobilis using dairy wastewater. Biochem. Eng. J. 36: 81-86.

Wu J.-Y., Ye H.-F. (2007) Characterization and flocculating properties of an extracellular biopolymer produced from a Bacillus subtilis DYU1 isolate. Process Biochem. 42: 1114-1123.

Xia S., Zhang Z., Wang X., Yang A., Chen L., Zhao J., Leonard D., Jaffrezic-Renault N. (2008) Production and characterization of a bioflocculant by Proteus mirabilis TJ-1. Bioresour. Technol. 99: 6520-6527.

Yim J.H., Sung J.K., Se H.A., Hong K.L. (2007) Characterization of a novel bioflocculant, p-KG03, from a marine Dinoflagellate, Gyrodinium Impudicum KG03. Bioresour. Technol. 98: 361-367.
Yokoi H., Natsuda O., Hirose J., Hayashi S., Takasaki Y. (1995) Characteristics of biopolymer flocculant produced by Bacillus sp. PY-90. J. Ferment. Bioeng. 79: 378-380.

Yokoi H., Yoshida T., Mori S., Hirose J., Hayashi S., Takasaki Y. (1997) Biopolymer flocculant produced by an Enterobacter sp. Biotechnol. Lett. 19: 569-573.

You Y., Ren N., Wang A., Ma F., Gao L., Peng Y., Lee D. (2008) Use of waste fermenting liquor to produce bioflocculants with isolated strains. Int. J. Hydrogen Energy, 33: 3295-3301.

Zhang J., Liu Z., Wang S., Jiang P. (2002) Characterization of a bioflocculant produced by the marine myxobacterium Nannocystis spp. NU-2. Appl. Microbiol. Biotechnol. 59: 517-522.

[online access] Flocculation: Theory and application. [access 21 April 2015] http://www.siltstop.com/pdf/flocculationtheory_application.pdf 